\title{
A pneumatological approach to transformational development: Implication for the church
}

\author{
Kakwata, Frederick \\ North-West University, Potchefstroom Campus \\ fkakwata@gmail.com
}

\begin{abstract}
This article seeks to articulate a biblical pneumatological approach to transformational development. The aim is to explore and examine the work of the Holy Spirit in Grudem's perspective and how it relates to transformational development. It is argued that the work of the Holy Spirit and the integral human development it brought amongst the early Christian community can function as a paradigm for the contemporary church globally, and particularly in Africa engaging in developmental work as well as for subsequent generations of Christians dealing with issues of transformation development.
\end{abstract}

Key words

Pneumatology; transformation; development; Holy Spirit; church

\section{Introduction}

Development represents the aspiration of numerous peoples and nations around the globe, and particularly in Africa. Although poverty affects every country in the world, sub-Saharan African countries are undoubtedly the most afflicted by poverty. States, non-governmental organisations, make massive effort, agencies and voluntary organisations design projects, and spend huge sums in an attempt to achieve development. Their effort is focused mainly on bringing about economic and social change in society.

In recent years, religion, which was marginalised in development processes, has become an emerging field of inquiry. This is because as Marshall and Van Saanen (2007:1) assert, there is an increasing interest in how religion affects development, also how development institutions should approach faith-based organisations thinking and impact on development. 
Several studies have been undertaken that pay particular attention to socio-economic implications of development brought about by religious organisations. But the role of the Holy Spirit, as the main Agent, has been absent or poorly represented in development discourse. However, without the guidance and the empowerment of the Holy Spirit, the effectiveness and the sustainability of transformation development are difficult to achieve (Myers 2011:80). Hence the necessity to understand the work of the Holy Spirit, and how it relates to development.

This article is based on a literature review, in which the author intends to investigate some of the ways in which the work of the Holy Spirit, according to the book of Acts, is related to transformational development. The focus is on core developmental values or principles flowing from the work of the Holy Spirit and their relationship to transformational development. The author believes that a pneumatological approach to transformational development has much to offer about the persisting poverty around the world and particularly in Africa.

\section{The concept of development}

Development is a multi-dimensional concept, with diverse meanings and no generally agreed definition. The lack of consensus on the definition of development has given rise to different interpretations and schools of thoughts. Very often this reality is understood as a process which enables human beings to realise their potential, build self-confidence, and lead lives of dignity and fulfilment; it is also a process which frees people from the fear of want and from political, economic or social oppression (Rist 2014:8).

It is clear that the term 'development' is often used to designate social and economic change that can uplift the life of the poor and provide an improved standard of living. Development can, therefore, be considered as an instrument for the alleviation or mitigation of poverty, and its key principle is participation. Wilson (2015:82) specifies that, this was recommended in 1992 UN Rio de Janeiro Earth Summit. The idea put forward he adds, was that community participation was of utmost importance in local development, in the sense that it can strengthen social sustainability. 
It should be mentioned that development is still a major issue in the postcolonial Africa, despite substantial flows of aid and the supply of technical assistance through the International Monetary Fund (IMF) and the World Bank (Bowers 2010:262). The various development issues that continue to challenge Africa are: food insecurity, poor access to health care, water, housing, global environmental change and global neoliberal economic policies (Asuelime, Yaro \& Francis 2014:1). Dembele (2012:181) attributes Africa's developmental backwardness to the failure of the neo-colonial management of African countries, as demonstrated by the external debt crisis that began in the late 1970s and led to the intervention by the World Bank and the IMF. He explains that these international institutions imposed on African countries the sad adjustment programmes which contributed to deepening the crisis in African states economies, bringing poverty to an ever-increasing level. Amaizo (2012:117) for his part blames the zerosum economic interaction with the West since independence as the cause of Africa developmental arrears. To bridge this gap Amaizo suggests the development of new theories and pragmatic solutions that derive from autonomous Africa-centred positions.

In the same vein, the post-development school of thoughts considers development (economic growth, industrialisation, and modernisation) as having failed to bring about development in the third world; it has rather contributed to the increase of the disparity between the rich and the poor. For that reason, post-development theorists articulate alternative development approach. The latter, as Ziai (2007:i, 5) indicates, is the conception of new social structures based on different conceptions of the economy that rely on solidarity and reciprocity, direct democratic politics and traditional knowledge. He further argues that post-development school of thought has been heavily criticised for overlooking the positive sides of modernity, development, science, technology and economic substitution. But the reality is that poverty remains a great challenge despite some progress made in certain areas, the gap between the rich and the poor is at the increase at the national as well as global level. 


\section{Transformational development}

With the aim of distinguishing Christian involvement in development activities from secular development, evangelicals and ecumenicals have been brought to sharpen the concept of development and term it 'transformation' (Sugden 2003:70-71). This idea as Bowers (2010:261) indicates in 1980s that the term development was too loaded with secular and humanistic freight and it was no longer useful. In addition Christians cannot make the same types of contribution to development as governments, or NGOs and secular private agencies. The model of development pursued by nonreligious organisations is exclusively oriented by the socio-economic approach. Even though such an approach may seem successful it will be limited if the dimension lacks the spiritual transformation of individuals. At this point, the role of the Holy Spirit in social transformation becomes evident. Bowers (2010:266) alludes to this when she emphasises that the ANC recognises that social transformation cannot be separated from spiritual transformation.

Social transformation, accordingly, refers to change in human relationships, communities and the living conditions of the people.

It is the processes of change in the condition of life of people, and the qualitative change in the nature and character of human societies (Groenwald 2000:18).

In the same vein, Winter, Steven and Hawthorne (1999:588) define transformation as the "change in the whole of the person, material, social and spiritual as well as in the community, economics, social, and political." This perspective carries God's vision for people and their communities that is to be transformed into the image and likeness of Christ (2 Cor 3:18). Bowers $(2010: 268,269)$ holds the same view and refers to transformation as an intrinsic part of God's plan for the world.

As already mentioned, for development to be transformational, it must be enlightened, guided, and empowered by the Holy Spirit. Wink (1992:84) rightly argues that "unjust social systems can only be changed by strategies that address the socio-spiritual nature of institutions." The Holy Spirit can, therefore, be seen as the source of power (Lk 24:49) that transforms lives and fosters integral human development of individuals in society. Accordingly, a development that is transformational is holistic, it changes individuals 
and social structures. This portrays the nature of salvation the Bible offers as August (2014:43) emphasises. Salvation should not be understood as being spiritual only or only changing peoples' lives, but it includes all aspects of human life, "it changes peoples' relationships and living conditions, it alters structures, in fact it changes the world". He further argues that the church is the only institution that can foster such transformation due to the nature of the church itself as a building community.

After having examined transformational development, the following section will focus on the work of the Holy Spirit in development.

\section{A pneumatological approach}

This section attempts to analyse the work of the Holy Spirit and how it relates to social transformation. The work of the Holy Spirit, as Grudem (1994:634) defines it, is the active manifestation of the presence of God in the world, and especially in the church and it includes:

- The empowerment of the Holy Spirit;

- Purification/sanctification;

- Revelation;

- Unity

Grudem emphasises an important point that the activities of the Holy Spirit do not just happen automatically amongst God's people; these activities depend on the faith and obedience of believers. This implies that the unbelief and disobedience of the people of God are the elements that stifle the Holy Spirit's activities in the lives of fellow humans.

\section{The Holy Spirit empowers}

The first distinctive work identified of the Holy Spirit is that the Spirit equips disciples for service (Stronstad 2012:58). The Holy Spirit has been at work since the Old Testament era to empower people for special services. During that time the empowerment of the Holy Spirit was restricted to a limited number of people such as prophets, priests or kings. For example Exodus 31:3-5 records that God filled Bezalel with that Spirit that gifted him with special skills to construct and furnish the tabernacle. The Spirit also endowed the early kings (such as Saul, David, 1 Sam. 10:10; 16:13) 
of Israel with special capabilities (Erickson 2013:792). However, the New Testament testimony indicates a radical change where the Holy Spirit is not restricted any more but is poured out on all people without distinction (Joel 2:28).

Therefore, the reception of the Spirit on the day of Pentecost inaugurated a new era of a charismatic community to fulfil Joel's prophecy (Joel 2:28-29; Acts 2:17-18). It should be noted that the term 'charismatic' is not used here to describe the neo-Pentecostal movement that emerged in the 1960s and 1970s, but to designate "God's gift of his Spirit to his servants, either individually or collectively, to anoint, empower, or inspire them for divine service" (Stronstad 2012:16).

The presence of the Spirit as Fee (2005:15) maintains is the renewed presence of eternal God, which means that by God own Spirit we live in the presence of God. The Spirit enabled disciples in the early Christian community to live up to the values of the kingdom of God, and not according to the patterns of their society. The various dimensions of development can be highlighted from this lived experience, as indicated below. Furthermore, it must be stressed that the empowerment of the Holy Spirit in the early community brought about transformation, not only for individuals, but to their environment as well.

Firstly, it is remarkable that the empowerment of the Holy Spirit on the disciples nurtured spiritual transformation. This can be seen in the formation of the idyllic community after the mass baptism in the Holy Spirit recorded in Acts 2:41-47 (Embudo 2017:19). The birth of the early Christian community is the result of the outpouring of the Holy Spirit and it portrays the quality of daily life among those who are baptized in the name of Jesus Christ (Green 2015:124). In addition, the disciples continued to perform wonders and signs and converted many people, who, in turn, devoted themselves to the teachings of the apostles and lived in the fear of God (Acts 2:42-43).

Secondly, the empowerment fostered social transformation, as Luke testifies, the early community continued devoting themselves to fellowship and brotherly love. As a result this common fellowship united disciples to the apostles teaching and also to their disposition to share goods (Embudo 2017:21). Green (2015:129) puts it clear that the economic sharing is a 
concrete enactment and expression of the believers' unity. He specifies that believers demonstrated their faith in economic solidarity by sharing voluntarily their possessions to address the plight of the needy.

Finally, it facilitated economic transformation. For example Acts 2:44-45 emphasises that the disciples expressed deep concern for the poor who were in their midst. They began selling off property and possessions, and were sharing these with those in need. But a complaint arose from the Hellenistic Jews that their widows were being overlooked on the daily distribution of food (Acts 6:1-3). To resolve this dispute, the disciples tasked the community to select seven men of good reputation, full of the Spirit

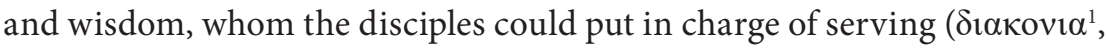
diakonia) at tables.

The selection criteria for the seven men to minister ( $\delta 1 \alpha \kappa \circ v 1 \alpha)$ in this regard is not to be taken lightly. These criteria shed light on the apostles' strategy to tackle the issue of poverty and facilitate development. The importance of the empowerment by the Holy Spirit in development work becomes evident. Witherington (1998:250) makes it clear that for the disciples the

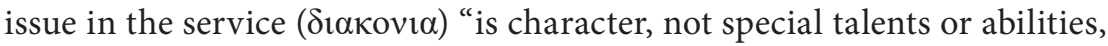
and on their being full of the Spirit". The requirement of $\sigma o \phi 1 \alpha$ (sofia, wisdom) implies that people engaging in services or development should have "the ability to discern the right thing to do when choices must be made" (Witherington 1998:250). It appears that this case refers to Spiritinspired wisdom, which portrays the full work of the Holy Spirit in the life of the believer. God's Spirit shapes the individual's character and provides wisdom. As a result, the disciples seem to have eliminated poverty from the community of saints, seeing that it was testified that "there was no needy person amongst them ..." (Acts 4:34). The outpouring of the Holy Spirit did not only affect the interior life of the community of believers but also the world around them. The community of believers enjoyed public support (Acts 2:47). As Green (2015:131) puts it "believers were agents of God's good gifts to the larger community."

1 As a definition, $\delta 1 \alpha \kappa o v i \alpha$ (diakonia) "is often understood as service. In many instances it has also been regarded as acts of charity and benevolence that have been conferred upon the less fortunate or needy in one's community" (Phiri and Dongsung 2013:253). 
It is commendable that development practitioners and NGOs in Africa have been working hard to promote justice and peace in the society. Their contribution to development, however, is limited mostly to economic aspects such as food supplies, providing medical care, jobs, or microloans for development projects. As mentioned above, the apparent success of development practitioners and NGOs is partial because their practice is not combined with the spiritual development of individuals. In other words, development is incomplete (not integrated) when the spiritual aspect is overlooked.

In contrast, the experience of the early Spirit-empowered community demonstrates that "the Holy Spirit is the primary tool in development as well as the eschaton of development both on a personal and a global social level" (Roux 2005:iii). This is because sin is the consequence of broken relationships at the personal as well as societal level which reaches its climax in self-centredness, it culminates in the oppression and exploitation of one by another and this can lead to poverty. Thus the presence of the Holy Spirit in the work of development is the power that brings the ability and guidance that can facilitate meaningful change in people's lives by restoring broken relationships with self, others and God. Furthermore, the spiritual dimension can be added to existing development efforts and processes. Thus the church can offer a complementary contribution to development activities that are incomplete and therefore not sustainable. The reason is that the church is historic heir to the ministry of the apostles through the empowerment of the Holy Spirit. For that reason Myers (2011:80) advocates that Christian development workers must expect and pray for the supernatural intervention of the Spirit, and this should form part of their lived spiritual strategy.

\section{The Holy Spirit purifies}

The Holy Spirit does not only empower believers for the ministry but also purifies and sanctifies them. By 'sanctification' Erickson (2013:797) means "the continued transformation of moral and spiritual character so that the believer's life actually comes to mirror the standing he or she already has in God's sight". Grudem (1994:639) understands the cleansing and sanctification from sin as one of the fundamental activities of the Holy Spirit. Several passages in the New Testament attest that sanctification 
is the work of the Holy Spirit in believers. For example, Paul confirms to the Corinthians, "You were washed, but you were sanctified, but you were justified in the name of our Lord Jesus Christ" (1 Cor 6:11). Paul urges the Thessalonians, "We should always give thanks to God for you, brethren beloved by the Lord, because God has chosen you from the beginning for salvation through sanctification by the Spirit and faith in the truth" (2 Thess 2:13).

Apparently the metaphor of fire that John the Baptist uses in the statement "He (Jesus) will baptise you with the Holy Spirit and fire" (Mt 3:11; Lk 3:16), symbolises the purifying function of the Holy Spirit (Garland 2011:159). It should be noted that through sanctification the Holy Spirit transfers a new nature to the believer, and it is a process that lasts throughout the life of the believer. The Spirit delivers holiness and the spiritual fruits mentioned in Galatians 5:22-23 which are: love, joy, peace, patience, kindness, goodness, faithfulness, gentleness, self-control, but the greatest amongst them is love. These qualities reflect the character of God (Grudem 1994:640).

From the exposition above it is evident that sanctification is the work of the Holy Spirit and is significant to transformational development. It liberates the believer from the law of $\sin$ (Rom 8:2), which directs the fallen character of humanity. As Roux (2005:64) explains, sin is deeply rooted in human existence and portrays the human situation that must be overcome by the sanctifying work of the Holy Spirit. Hence the believer no longer lives or walks according to the flesh which is the old nature but by the Spirit, because the Holy Spirit dwells in him (Rom 8:5-6).

According to the New Testament testimony, God predestined the Christian believers to this above-mentioned life of the Spirit (Erickson 2013:797). Life in the Spirit brings about holistic transformation in the life of believers, the society and their surrounding environment. In the Spirit-filled life leading to full transformation lies the essence of Christianity. Roux (2005:25) states that the relevant role of Christianity in society consists of fostering a just social environment. This can be made possible by the church acting as the instrument of the Spirit to transform people from their selfish interest and become members of the society that work for the good of others.

Transformation from sin is also concerned with poverty, oppression and the integral liberation of human beings and their society. As Myers 
(2011:316) states, "The goals of Christian witness are the same as the goals of transformation development: changed people and changed relationships ... this comes only by restoring the family of relationships of which we are a part". From a developmental point of view, churches can contribute significantly by putting in efforts to transform people's relationships, rather than limiting their development to a mere economic approach such as supplying food to the hungry or providing medical care.

\section{The Holy Spirit reveals}

Another work of the Holy Spirit in the lives of believers is to reveal. The revelatory work of the Holy Spirit can be noticed in the fact that the Spirit inspired and revealed God's words to the Old Testament prophets and New Testament apostles and, in many instances, these words were placed into the Scriptures (Grudem 1994:640). This is evident from several passages in the Bible.

Firstly, the Lord sent His Word by His Spirit and conveyed it through His prophets, as Zechariah prophesised: "And they made their hearts like flint so that they could not hear the law and the words which the Lord of hosts had sent by His Spirit through the former prophets; therefore, great wrath came from the Lord of hosts" (Zech 7:12). Secondly, the Holy Spirit provided guidance and direction to the people of God.

Generally, the Holy Spirit guides and teaches the believer through the Word of God as Paul attests, "all Scripture is inspired by God and profitable for teaching, for reproof, for correction, for training in righteousness; that the man of God may be adequate, equipped for every good work" (2 Tim 3:1617). Nevertheless, there are certain details in people's daily lives that the Bible does not mention explicitly in situations as these, the enlightenment of the Holy Spirit is needed to give direction to the believer. There are several incidences reported in the Bible, particularly in the New Testament, where the Holy Spirit gives direct guidance to various people in specific circumstances of life. For example:

- As Philip drew near the Ethiopian chariot, "the Spirit said to Philip, go up and join this chariot" (Acts 8:29).

- The apostle Peter received a direction after he saw a vision that troubled him and he was uncertain how to interpret it. "And while 
the apostle Peter was reflecting on the vision, the Spirit said to him, behold, three men are looking for you. But arise, go downstairs, and accompany them without misgivings; for I have sent them myself" (Acts 10:19-20).

- The church of Antioch received a clear direction, "While they were ministering to the Lord and fasting, the Holy Spirit said, set apart for me Barnabas and Saul for the work to which I have called them" (Acts 13:2).

In these instances, the Holy Spirit may have used use various ways to communicate his direct guidance to believers: audible (e.g. the voice Paul heard on the road to Damascus, Acts 9:4-6), mentally, or through visions and dreams (e.g. a call in a night vision to go to the Macedonians to preach the gospel, Acts 16:19). The Holy Spirit also directed believers through spiritual gifts such as prophecy (1 Cor 14:29-33) as the Scripture testifies: "For no prophecy was ever made by an act of human will, but men moved by the Holy Spirit spoke from God" (2 Pet 1:21).

Revelation is also a useful developmental instrument that is often neglected or less discussed in the development discourse. For example, specific causes of poverty in people's lives or communities may have a spiritual origin that human intellect is unable to perceive. In this case revelation that comes from the Holy Spirit can give to believers a view into the spiritual realm, which provides an in-depth understanding of the situations we face with in the physical world. Myers (2011:143) alludes to this reality when he states that the spiritual dimension of poverty seldom surfaces in the development schemes. The danger is that, "God and God's revelation are banished from our social analysis, and we are left to interpret our world for ourselves" (Myers 2011:11). Revelation is not an automatic occurrence. The example above shows that when the church of Antioch was praying and fasting the revelation was given that led Paul and Barnabas into mission.

In this regard, the author concurs with Myers (2011:11) that "prayer, fasting, meditation, and other forms of spirituality become spiritual activities relegated to knowing things about the spiritual world". The prophet Isaiah emphasises the necessity of seeking God's direction: "Woe to the rebellious children, declares the Lord, who execute a plan, but not mine, and make an alliance but not of my Spirit" (Isa 30:1). In this verse, Isaiah is lambasting 
people who were making decisions according to their own wisdom and common sense, but did not orient their heart to seek God's direction before attempting any agreement.

\section{The Holy Spirit unifies}

A further divine work of the Holy Spirit is unifying the church. The Apostle's Creed also strongly emphasises the unity of the church by the following confession: I believe in the Holy Spirit, the Holy Catholic Church, the communion of the saints ... As mentioned previously, after the outpouring of the Holy Spirit on the day of Pentecost, the apostle Peter confirmed the fulfilment of Joel's prophecy. The prophecy states that in the last days the Lord will pour out His Spirit on all people, sons and daughters shall prophesy, young men shall see visions and the old men shall dream dreams; this even applies to the men and female servants and maidservants in those days (Joel 2:28-32; Acts 2:16-18). Thus the descent of the Holy Spirit on the disciples on the day of Pentecost marked the birth of a new community characterised by exceptional unity as Luke's narrative depicts the situation (Acts 2:44-47):

This attitude of common sharing, as Schnabel (2012:181-182) argues, is an expression of the real life characterised by love and care that believers in Jesus have demonstrated in practice for each other. For Schnabel (2012:181), the reality of the community of believers entails the transformational power of the Spirit bringing about the renewed society that the prophet Joel predicted. This occurred when believers experienced the year of the Lord's favour and time of refreshment (Lk 4:19; Acts 3:19). The fact that the early Christians sold their possessions to support the needy portrays pragmatic ethics with regard to possessions where the needs of the poor take precedence (Schnabel 2012:182).

It is interesting to note that Paul in his benediction prayer to the Corinthians, attributes the unifying function to the Holy Spirit: "The grace of the Lord Jesus Christ, and the love of God, and the fellowship of the Holy Spirit be with you all" (2 Cor 13:14). In a similar vein, Paul writes to the Philippians:

If there is any encouragement in Christ, if there is any consolation of love, if there is any fellowship of the Spirit, if any affection and compassion, make my joy complete by being of the same mind, 
maintaining the same love, united in spirit, intent on one purpose (Phil 2:1-2).

Paul discusses the same theme of the unifying work of the spirit in several other passages of the New Testament (Eph 4:3; 1 Cor 12:21; etc.). It also can be argued that the unity of the Spirit is an active expression of love. In other words, the Holy Spirit pours out God's love in the hearts of believers (cf. Rom 5:5), and this love entails the perfect bond of unity (Col 3:14). Grudem (1994:647) rightly argues that the eminent sign that the Holy Spirit is working to manifest God's presence is sound harmony in the church community and mutual overflowing love amongst the members. The fact that love binds together in perfect accord confirms the unifying function of the Holy Spirit.

Unity brought about by the Spirit is a developmental value since it transforms people. Such unity portrayed the inner life of the early church. This new community lived daily in constant fellowship. A strong sense of unity and compassion were built under the impulse of the Holy Spirit. They shared common goods and sold their possessions, caring for one another. These acts demonstrated their mutual love concretely. It is clear that there is a link between the gift of the Spirit and the fruit of the Spirit, which is love. Jesus stated that, "All men will know that you are my disciples if you love one another" (John 13:35 NIV). Roux (2005:53) argues that the creation of this love urges people to respond to the pain and injustice of other people, and in doing so they advance the kingdom of God on earth.

\section{Conclusion}

The author analysed the four aspects of the work of the Holy Spirit namely the empowerment of the Holy Spirit, purification/sanctification, revelation and unity as Grudem (1994:634-650) described them and their relation to transformational development. In the process it was noticed that the work of the Holy Spirit undoubtedly played a significant role in effecting personal and social transformation in the early Christian community. It was demonstrated that the empowerment of the Holy Spirit is important in developmental work. The Spirit shapes to the individual's character and gives wisdom which is a value the apostles required to development practitioners. In addition, sanctification which is the work of the Holy Spirit 
is significant to development as well. It liberates the believer from the law of sin. The latter is the element that disrupts human beings relationships at various levels which are considered as the root causes of poverty. Thus transformation from sin is also concerned with poverty, oppression, and the integral liberation of human beings and their society.

Another useful developmental tool emphasised is Revelation. The latter can reveal to believers things in the spiritual world which provides an in-depth understanding of the situations (such as poverty) we are facing with in the physical world. Finally, unity is also a developmental value that transforms people and their relationships, demonstrates love the Holy Spirit pours into the hearts of believers. However, love is the negation of sin. The virtue of love is therefore the key factor for the remedial action for sin and poverty.

According to the New Testament testimony, the disciples needed the empowerment of the Holy Spirit which helped them contribute to the developmental work of promoting spiritual, social and physical transformation both at the individual and collective level. In the same sense, the wider Christian church, particularly in Africa, ought to have the empowerment of the Spirit to make the same type of contribution.

\section{References}

Amaizo, Y.E. 2012. An alternative African developmentalism: A critique of zero-sum game and palliative economics. African development. [Online]. Available: https://www.ajol.info/ind [Online] Available: https:// www.ajol.info/index.php/ad/article/viewFile/87487/77169 [Accessed: 2018, May 14].

Asuelime, L., Yaro, J. \& Francis, S. 2014. Selected themes in African development studies: economic growth, governance and the environment. Cham: Springer.

August, K.T. 2010. Equipping the saints: God's measure for development. Cape Town: The Print Man.

Blight, R.C. 2007. An exegetical summary of Luke 1-11. Dallas, TX: SIL International.

Bock, D.L. 1994. Luke. Vol. 1 1:1-9:50. Grand Rapids, MI: Baker Academic. 
Bowers, N.D. Moving from development to social transformation. Development in the context of Christian mission. In: Religion and Social Development in Post-apartheid South Africa Perspectives for critical engagement. Stellenbosch: Sunpress. 261-273.

Dembele, D.M. 2012. Africa's Developmental Impasse: Some Perspectives and Recommendations. Africa Development. [Online]. Available: file:///C:/Users/FREDRI 1/App Data/Local/Temp/87489-216596-1-PB.pdf [Accessed: 2018, May 14].

Dempster, M.W., Klaus, B.D., \& Petersen, D. 1991. Called \& empowered: Global mission in Pentecostal perspective. Peabody, MA: Hendrickson Publishers.

Embudo, L.A. 2017. A Lukan Paradigm of Witness: Community as a Form of Witness Part II. Asian Journal of Pentecostal Studies. [Online]. Available: http://nwulib.nwu.ac.za/login?url=http://search.ebscohost.com/login.aspx? direct=true\&db=aph\&AN=121986027 [Accessed: 2018, May 10].

Erickson, M.J. 2013. Christian theology. $3^{\text {rd }}$ ed. Grand Rapids, MI: Baker Academic.

Fee, G. 2005. Paul the Spirit and the people of God. Peabody, Massachusetts: Hendrickson Publishers.

Garland, D.E. 2011. Luke, Zondervan exegetical commentary on the New Testament. Grand Rapids, MI: Zondervan.

Green, J.B. 2015. Conversion in Luke-Acts: divine action, human cognition, and the people of God. Grand Rapids, Michigan: Baker Academic.

Groenewald, C. 2000. Social transformation: between globalization and localization. Scriptura. [Online]: Available: http://scriptura.journals.ac.za/ pub/article/viewFile/1241/1172 [Accessed: 2018, May 14].

Grudem, W. 1994. Systematic theology: an introduction to biblical doctrine. Leicester, England: Inter-Varsity Press.

Marshall, K. \& Van Saanen. 2007. Development and faith: where mind, heart, and soul work together. Washington DC: World Bank.

Miller, D.E. \& Yamamori, T. 2007. Global Pentecostalism: the new face of Christian social engagement. Berkeley, Los Angeles: University of California Press. 
Myers, B.L. 2011. Walking with the poor. Principles and practices of transformation development. New York, NY: Orbis.

Phiri, I.A. \& Dongsung, K. (2013). Called to be a diaconal community through a pilgrimage of justice and peace. The Ecumenical Review. [Online]. Available: http://osegenius1.urbe.it/pro/reseource?uri=30000056933\&v=I $\& d c n r=5$ [Accessed: 2018, April 16].

Rist, G. 2014. The history of development from Western origins to global faith. New York: Zed Books.

Roux, A. 2005. The Holy Spirit and development. Unpublished master's thesis. Pietermaritzburg: University of Kwazulu Natal,

Schnabel, E.J. 2012. Zondervan exegetical commentary on the New Testament. Grand Rapids, MI: Zondervan.

Stronstad, R. 2012. Spirit Scripture and theology: A Pentecostal perspective. Baguio City: Asia Pacific Theological Seminary Press.

- 2012. The charismatic theology of St. Luke: Trajectories from the Old Testament to Luke-Acts. $2^{\text {nd }}$ ed. Grand Rapids, MI: Baker Academic.

Sugden, C. 2003. Transformational development: Current state of understanding and practice. Transformation. [Online]. Available: http://search.escohost/login.aspx?direct=rfh\&AN=ATLA0001448628\&site=ehostlive\&scope=site

Wilson, S.N. 2015. Identity, Culture and the Politics of Community Development. Cambridge:

Cambridge Scholars Publishing.

Wink, W. 1992. Engaging the Powers: Discernment and Resistance in a World of Domination. Minneapolis: Fortress Press.

Winter, R.D., Steven, C., \& Hawthorne, S.C. 1999. Perspectives on the World Christian Movement. A reader. $3^{\text {rd }}$ ed. Pasadena, CA: William Carey Library.

Witherington, B. 1998. The Acts of the Apostles: A socio-rhetorical commentary. Grand Rapids, MI: W.B. Eerdmans.

Ziai, A. 2007. Exploring post-development theory. Theory and practice, problems and perspectives. New York: Routledge. 